\title{
ANALISIS KARAKTERISTIK MATERIAL KOMPONEN PADA RANCANG BANGUN MESIN ROBOT DRAWING HYBRID LASER
}

\author{
SUMARNO $^{1}$, SLAMET RIYADI $^{2}$, ALI MACMUDI ${ }^{3}$ \\ Program Studi Teknik Mesin, Fakultas Teknik, Universitas Muhammadiyah Tangerang \\ Jl. Perintis Kemerdekaan I/33 Cikokol-Tangerang \\ E-Mail : bagosumarno76@gmail.com
}

\begin{abstract}
ABSTRAK
Mesin Robot Drawing Hybrid Laser merupakan Mesin yang dikontrol oleh komputer dengan menggunakan bahasa numerik (data perintah dengan kode angka, huruf dan simbol) sesuai standar ISO. Mesin Robot Drawing Hybrid Laser ini menggunakan software-software antara lain Arduino, Processing, Camotic, Laser GRBL dan Inkscape. Mesin Robot Drawing Hybrid Laser sangat membantu dalam membuat penggambaran pola dan pengenalan pola. Adapun beberapa hardware-nya yaitu Arduino Uno, CNC Shield v3, DRV8825, Motor Stepper Nema 17, dan komponen mekaniknya. Dan untuk permodelannya 2 in 1 bisa digunakan keduanya dengan satu Mesin. Mesin Robot Drawing Hybrid Laser ini termasuk mesin CNC, karena dalam pengoperasiannya menggunakan kode-kode NC. Kode tersebut didapat dari gambar yang telah diterjemahkan menggunakan aplikasi Laser GRBL. Penelitian ini bertujuan untuk mengetahui bahan material yang digunakan untuk komponen Mesin Robot Drawing Hybrid Laser, ketika mesin beroperasi pasti ada bagian komponen yang mengalami kerusakan dan penulis memberi solusi dengan membuat komponen yang rusak tersebut dengan bahan lain. Material yang digunakan untuk poros rail berupa stainless steel, puli menggunakan bahan alumunium, serta main frame, box transmission, bracket dan plotter menggunakan bahan plastik filamen PLA (Polylactid Acid). Bahan-bahan yang digunakan untuk komponen mekanik disesuaikan dengan kebutuhan rancang bangun, komponen yang terjadi kerusakan adalah plotter dengan bahan plastik PLA karena saat terjadi gaya sebesar 20 Newton komponen tersebut akan patah. Dan bahan plotter berupa plastik PLA dan PETG tidak mempengaruhi hasil gambar atau pola yang dikerjakan.
\end{abstract}

Kata Kunci : Gokart; Mesin diesel MDX 186 FA; Injektor,Timing.

\begin{abstract}
Hybrid Laser Drawing Robot Machine is a machine that is controlled by a computer using a numeric language (data commands with numeric, letter and symbol codes) according to ISO standards. This Hybrid Laser Drawing Robot Machine uses software including Arduino, Processing, Camotic, GRBL Laser and Inkscape. Hybrid Laser Drawing Robot Machine is very helpful in making pattern drawing and pattern recognition. As for some of the hardware, namely Arduino Uno, CNC Shield v3, DRV8825, Nema 17 Stepper Motor, and mechanical components. And for the 2 in 1 modeling, both of them can be used with one machine. This Hybrid Laser Drawing Robot Machine is a CNC machine, because in its operation it uses NC codes. The code is obtained from the image that has been translated using the GRBL Laser application. This study aims to determine the materials used for the components of the Hybrid Laser Drawing Robot Machine, when the machine operates there must be a component part that is damaged and the author provides a solution by making the damaged component with other materials. The material used for the rail axle is stainless steel, pulleys are made of aluminum, and the main frame, transmission box, bracket and plotter are made of PLA (Polylactid Acid) filament plastic. The materials used for mechanical components are adjusted to the design needs, the component that is damaged is a plotter with PLA plastic material because when a force of 20 Newton occurs the component will break. And the plotter material in the form of PLA and PETG plastic does not affect the results of the drawing or pattern being worked on.
\end{abstract}

Keywords: Go-kart; MDX 186 FA Diesel Engine; Injectors; Timing.

\section{PENDAHULUAN}

Mekatronika adalah teknologi atau rekayasa yang menggabungkan teknologi tentang mesin, elektronika, dan informatika untuk merancang, memproduksi, mengoperasikan dan memelihara sistem untuk mencapai tujuan yang diamanatkan. Seperti diketahui dari definisi mekatronika adalah gabungan disiplin teknik mesin, teknik elektro, teknik informatika, dan teknik kendali.

Mesin Robot Drawing Hybrid Laser Adalah suatu alat yang memiliki 2 fungsi sekaligus yaitu digunakan untuk membuat tulisan, objek, pola atau gambar menggunakan pulpen dan laser yang terpasang pada sumbu Y. Alat ini memiliki 2 sumbu yaitu $\mathrm{X}$ dan $\mathrm{Y}$. Dalam bekerjanya alat ini 
menggunakan kontroler: Arduino Uno, CNC Shield V3, DRV 8825. Mekanisme penggeraknya menggunakan 2 buah Motor stepper jenis Nema 17. Power supply-nya DC 12V 5A. Untuk lasernya berkekuatan $1000 \mathrm{~mW}$. Dalam mencetaknya, alat ini berkapasitas maksimal $\mathrm{X}=33 \mathrm{~cm}$ dan $\mathrm{Y}=23 \mathrm{~cm}$. Untuk aplikasi desainnya menggunakan software Inkscape dan dalam pengoperasiannya menggunakan software Laser GRBL.

Pemilihan bahan-bahan material untuk sebuah rancang bangun Mesin sangat berpengaruh terhadap kekuatan, fungsi, dan biaya untuk sebuah rancang bangun. Pada saat sebuah mesin digunakan pasti ada bagian komponen yang mengalami kerusakan, oeh sebab itu penulis akan menganalisa kerusakan terebut menggunakan software Solidworks. Selanjutnya penulis akan memberikan solusi untuk mengatasi masalah tersebut dengan membuatkan komponen dengan desain dan jenis bahan yang berbeda. Setelah itu penulis akan membandingkan kedua komponen tersebut untuk mengetahui perbedaan keduanya yang ditinjau dari hasil simulasi, biaya bahan dan pengerjaan serta hasil gambar/pola yang dikerjakan.

Oleh sebab itu, penulis mengambil judul penelitian "Analisis Karakteristik Material Komponen pada Rancang Bangun Mesin Robot Drawing Hybrid Laser".

\section{METODOLOGI PENELITIAN}

\subsection{Metode Pengumpulan Data}

Prosedur dalam penelitian ini dimulai dengan studi literatur yaitu mencari dan mengumpulkan referensi serta dasar teori yang diambil dari berbagai buku penunjang penelitian, artikel dan jurnal untuk mendukung analisis karakteristik material komponen pada rancang bangun Mesin Robot Drawing Hybrid Laser. Metode yang digunakan untuk memecahkan permasalahan adalah dengan menggunakan langkahlangkah berikut :

1) Studi Pustaka

Penulis mengumpulkan data yang diperoleh dari materi kuliah, buku literatur , laporan penelitian, karangan ilmiah jurnal, peraturan, ketetapan, dan sumber-sumber tertulis baik tercetak maupun elektronik yang berhubungan dengan penelitian ini.

\section{2) Observasi}

Pengumpulan data yang dilakukan dengan cara menggandakan penelitian secara langsung pada obyek penelitian dalam penelitian ini penulis mengadakan pengamatan di workshop yang bertempat di Kp. Iwul No. 007 RT 02 RW 02, Desa Tobat, Kecamatan Balaraja, Kabupaten Tangerang.

\section{3) Wawancara}

Melakukan wawancara dengan pembuat rancang bangun Mesin Robot Drawing Hybrid Laser serta diberi arahan oleh dosen pembimbing.

4) Eksperimen

Percobaan pengumpulan data dilakukan dengan mengadakan penelitian secara langsung pada obyek penelitian.

Eksperimen pada penelitian ini ialah plotter berbahan plastik didesain dan dianalisa kerusakannya menggunakan Solidworks simulation serta pengujian plotter dengan variasi bahan antara plastik PLA dengan plastik PETG.

\subsection{Metode Penelitian}

Pada penelitian ini penulis menggunakan metode eksperimen, dimana metode eksperimen merupakan metode penelitian yang digunakan untuk mencari pengaruh perlakuan tertentu terhadap yang lain dalam kondisi yang terkendalikan (sugiono: 2010). Metode yang digunakan adalah analisa kekuatan plotter berbahan plastik filamen jenis PLA (Polylactic Acid) menggunakan software Solidworks, selanjutnya penulis membuat plotter dengan desain baru dan bahan lain yaitu PETG (Polyethylene Terephthalate Glycol) dan mensimulasikan juga menggunakan software Solidworks untuk mengetahui kekuatan masing-masing plotter.

\subsection{Instrumen Penelitian}

Instrument penelitian adalah suatu alat yang digunakan untuk mengukur fenomena alam maupun sosial yang diamati. Secara spesifik semua fenomena ini disebut variabel penelitian. Instrument penelitian yang digunakan antara lain :

1) Laptop

Alat yang digunakan untuk mengolah data dan proses simulasi menggunakan software Solidworks. Dengan spesifikasi sebagai berikut:

Tabel 1. Spesifikasi Laptop yang Digunakan

\begin{tabular}{|c|l|l|}
\hline No. & \multicolumn{2}{|c|}{ Spesifikasi } \\
\hline 1 & $\begin{array}{l}\text { Computer } \\
\text { name }\end{array}$ & LAPTOP-JQB1KCL0 \\
\hline 2 & $\begin{array}{l}\text { Operating } \\
\text { System }\end{array}$ & $\begin{array}{l}\text { Windows 10 Home Single } \\
\text { Language 64-bit }\end{array}$ \\
\hline 3 & $\begin{array}{l}\text { System } \\
\text { Model }\end{array}$ & HP Laptop 14-bwOxx \\
\hline 4 & Processor & $\begin{array}{l}\text { AMD A9-9420 } \\
\text { RADEON R5 }\end{array}$ \\
\hline 5 & RAM & 12288 MB \\
\hline
\end{tabular}

2) Software Solidworks

Aplikasi yang digunakan untuk menganalisa komponen pada Mesin Robot Drawing Hybrid Laser 


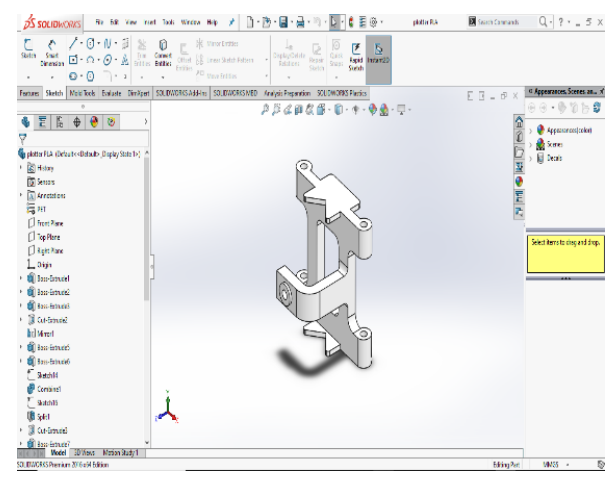

Gambar 1. Tampilan Aplikasi Solidworks 2016

3) Kertas ukuran A4 HVS 80 gram plotter.

Kertas digunakan untuk media pengujian

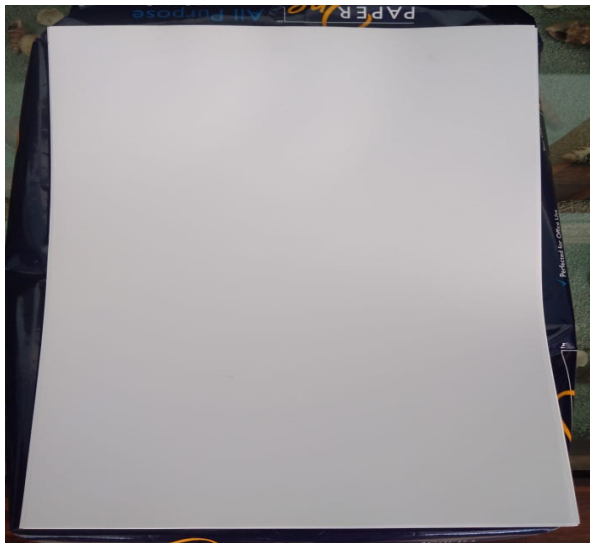

Gambar 2. Kertas HVS yang digunakan

4) Plotter dengan bahan plastik PETG

Suatu komponen pada Mesin Robot Drawing Hybrid Laser yang digunakan untuk menjepit alat tulis.

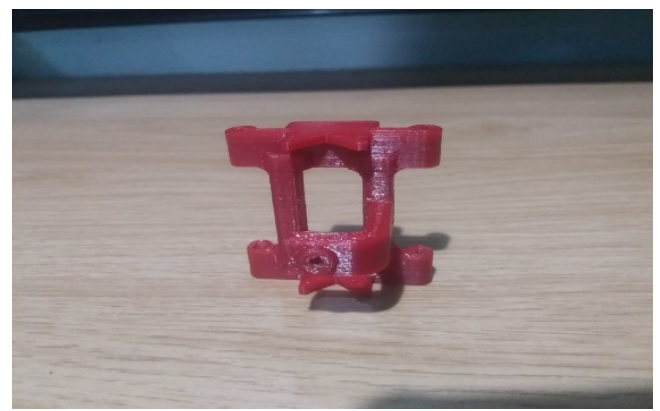

Gambar 3. Desain Baru Plotter dengan Bahan PETG

5) Alat tulis/pulpen

Alat yang digunakan untuk pembuatan pola/gambar pada media kertas.

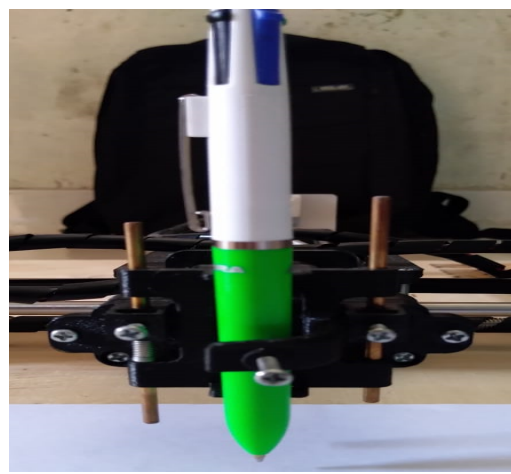

Gambar 4. Pulpen yang digunakan

6) Mistar baja

Alat yang digunakan untuk mengukur dimensi komponen pada rancang bangun Mesin Robot Drawing Hybrid Laser.

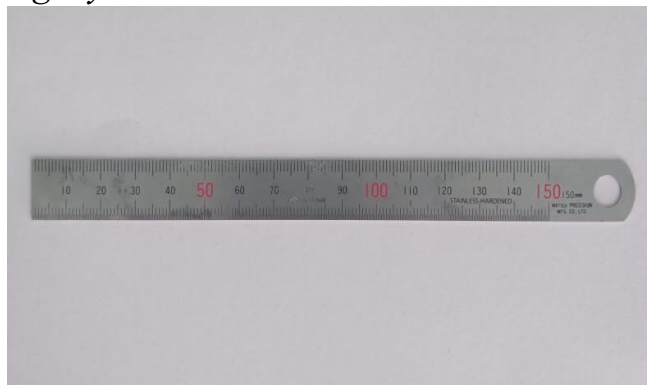

Gambar 6. Mistar Baja yang Digunakan

7) Jangka Sorong Digital

Alat yang digunakan untuk mengukur dimensi komponen pada rancang bangun Mesin Robot Drawing Hybrid Laser.

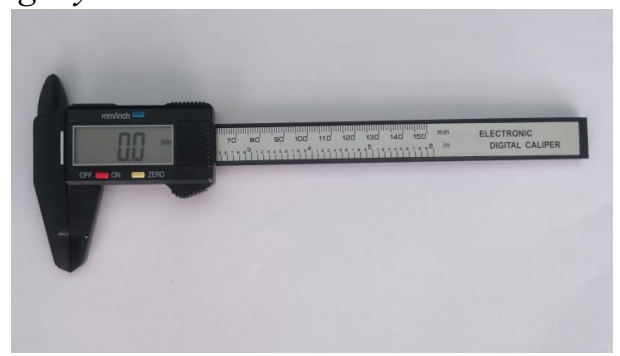

Gambar 7. Jangka Sorong Digital yang Digunakan

8) Obeng plus dan minus

Alat yang diguanakan untuk membuka dan mengencangkan baut pada Mesin Robot Drawing Hybrid Laser.

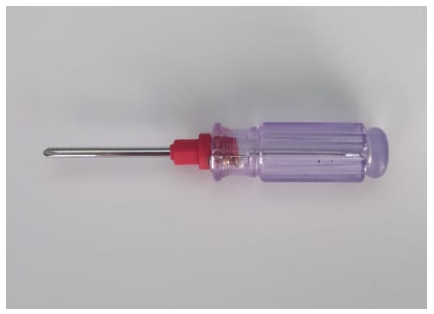

Gambar 8. Obeng yang Digunakan 
9) Mesin Robot Drawing Hybrid Laser

Alat dan bahan pada rancang bangun Mesin Robot Drawing Hybrid Laser terdiri dari komponen mekanik, komponen elektrik dan software.

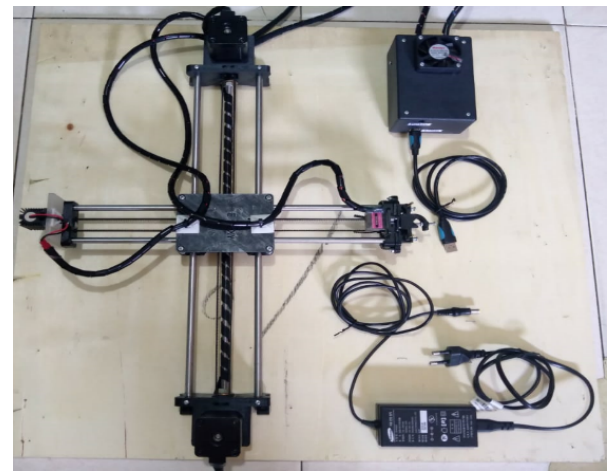

Gambar 9. Mesin Robot Drawing Hybrid Laser

\section{HASIL DAN PEMBAHASAN}

3.1 Pemilihan Bahan Untuk Komponen Mekanik Mesin Robot

Komponen-komponen mekanik yang terdapat pada Mesin Robot Drawing Hybrid Laser antara lain:

1) Poros Rail dengan bahan stainless steel yang memiliki sifat tahan karat, kuat.

2) Poros Guiden, Bearing besar dan bearing kecil bahannya baja yang memiliki sifat kuat.

3) Sabuk (belt) bahannya karet memiliki sifat ringan, kuat.

4) Puli bergerigi dan tidak bergerigi bahannya alumunium emmepunyai sifat ringan dan tahan karat.

5) Baut, Mur dan Ring menggunakan bahanbahan yang standar.

6) Main Frame, Plotter (alat penjepit pulpen), Bracket Laser dan Plotter, Box Transmission, Box Controller menggunakan bahan plastic filament PLA yang memiliki sifat ringan, ramah lingkungan dan murah.

Pada bagian poros rail dan guiden menggunakan bahan baja yang memiliki keuntungan kuat, dan mudah didapat. Pada bagian sabuk (belt) menggunakan bahan karet karena proses pergerakan secara mekanis tidak terlalu berat beban yang digerakkan. Pada bagian bearing besar ukuran disesuaikan dengan diameter poros rail, dan pada bearing kecil disesuaikan dengan lebar sabuk (belt) baik bearing besar dan kecil menggunakan bahan baja. Untuk bagian diameter Puli bergerigi ukuran disesuaikan dengan diameter motor stepper, geriginya disesuaikan dengan bentuk gigi pada sabuk (belt) dan puli tidak bergerigi ukuran disesuaikan dengan lebar sabuk (belt) agar transmisi berjalan dengan baik, kedua puli tersebut menggunakan bahan alumunium. Untuk main frame, bracket plotter dan laser, box transmission, box controller, plotter menggunakan bahan plastik filamen PLA yang memiliki sifat mudah dicetak dan murah untuk proses pembuatannya di workshop 3D Printer. Untuk baut, mur dan ring disesuaikan juga dengan ukuran komponen-komponen tersebut.

\subsection{Kerusakan Komponen Mesin Robot Drawing Hybrid Laser}

Kerusakan yang terjadi pada komponen Mesin Robot Drawing Hybrid Laser adalah pada bagian plotter yang berbahan plastik PLA. Alat ini berfungsi untuk menjepit alat tulis/pulpen untuk membuat pola/gambar. Komponen ini terletak pada sumbu Y Mesin Robot Drawing Hybrid Laser dan dipasang pada bracket plotter berbahan plastik juga dengan bantuan 2 pin baja dan 2 pegas yang terpasang pada lubang plotter diameter $3 \mathrm{~mm}$ lalu pin baja dan pegas diikat dengan 2 baut ke bracket plotter. Dan plotter sistem kerjanya naik-turun sesuai perintah program yang sedang dikerjakan. Untuk plotter berbahan plastik PLA yang rusak seperti gambar di bawah ini:

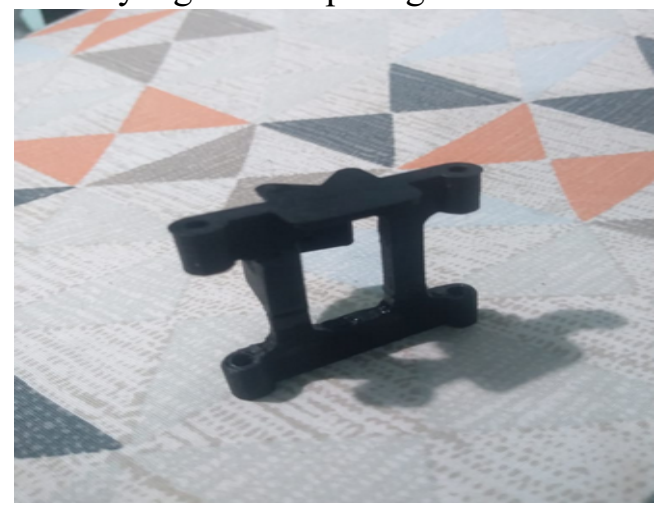

Gambar 10. Plotter yang Patah/Rusak

Sesuai dengan hasil simulasi yaitu tegangan maksimum pada plotter bahan PLA melebihi angka yield strength dan angka keamanannya di bawah 1 .

Plotter bahan PLA saat penulis simulasikan menggunakan software Solidworks dengan memberikan gaya sebesar 20 Newton mendapatkan hasil tegangan maksimal yang melebihi angka yield strength $3,8 \times 10^{7}$ $\mathrm{N} / \mathrm{m}^{2}$, sehingga pada saat komponen menerima gaya sebesar itu maka akan rusak/patah. Komponen ini sifatnya ringan, mudah rusak, dimensi bagian yang patah tebalnya hanya $4 \mathrm{~mm}$. 


\subsection{Perbandingan Menggunakan Plotter Bahan PLA Dengan PETG}

Untuk mengetahui perbandingan menggunakan plotter bahan plastik filamen PLA (Polylactid Acid) dengan plotter bahan plastik filamen PETG (Polyethylene Terephthalate Glycol) ini akan ditinjau dari: hasil simulasi, biaya bahan dan pengerjaan serta hasil gambar yang dikerjakan.

\section{A. Dari hasil simulasi}

\section{1) Desain awal plotter dengan bahan PLA}

\section{a) Strees (Tegangan)}

Tegangan adalah hasil perhitungan hubungan tegangan dan regangan pada model benda atau alat, regangan diperoleh dari deformation yang dialami model atau part yang diuji. Tegangan maksimum terjadi pada posisi di dekat lengkungan yaitu sebesar $4,0 \times 10^{7} \mathrm{~N} / \mathrm{m}^{2}$ dan tegangan minimumnya adalah $3,3 \times 10^{6} \mathrm{~N} / \mathrm{m}^{2}$.

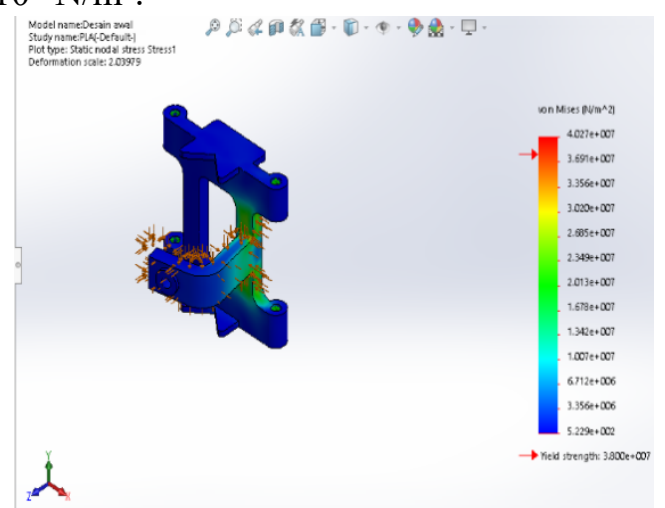

Gambar 11. Hasil Strees Desain Awal Plotter dengan Bahan PLA

b) Displacement (Perubahan Bentuk) Hasil Displacement pada plotter tersebut adalah $2,7 \mathrm{~mm}$.

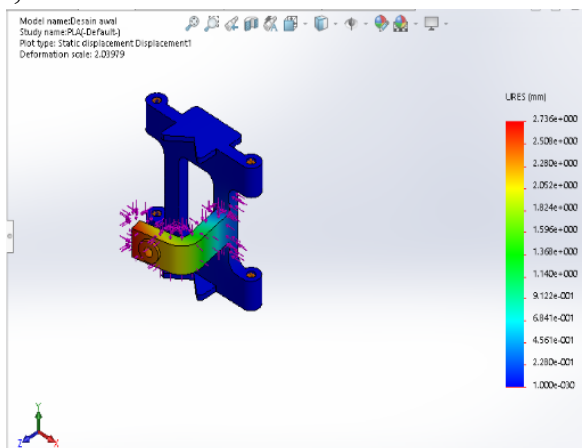

Gambar 12. Hasil Displacement Desain Awal Plotter dengan Bahan PLA

\section{c) Strain (Regangan)}

Hasil Strain (regangan) pada plotter tersebut adalah $1,1 \times 10^{-2} \mathrm{~N} / \mathrm{m}^{2}$.

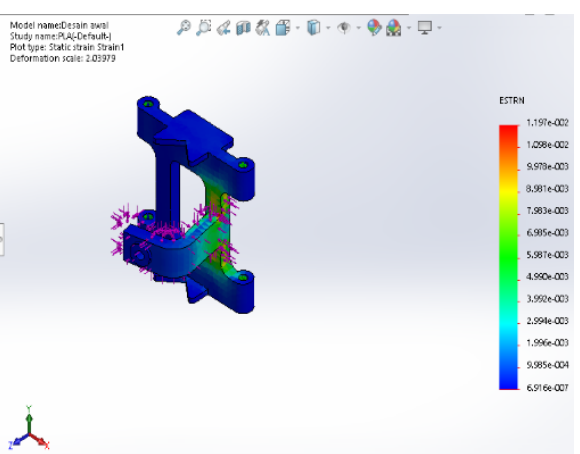

\section{Gambar 13. Hasil Strain Desain Awal Plotter dengan} Bahan PLA

\section{d) Factor Of Safety/FOS (Faktor Keamanan)}

Adalah angka keamanan yang terdapat pada setiap desain. Faktor keamanan diperhitungkan dengan acuan pada hasil pembagian dari besar tegangan ijin (yield strength) dibagi dengan tegangan yang terjadi. Berikut ini hasil factor of safety (faktor keamanan) yang terjadi:

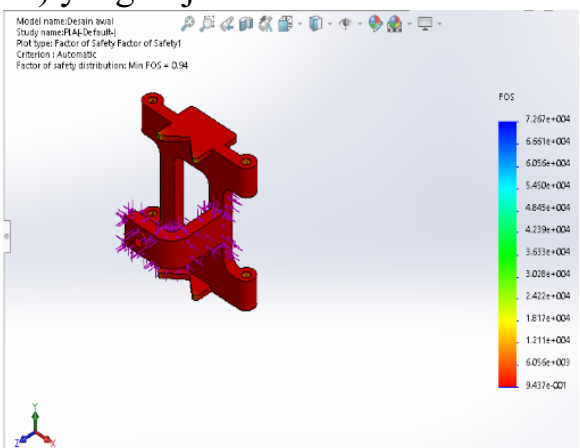

\section{Gambar 14. Hasil Factor of safety desain swal plotter} dengan bahan PLA

Pada Gambar 14 di atas diperoleh angka keamanan minimumnya 0,9 . Maka pada saat plotter bahan PLA menerima gaya sebesar 20 Newton, maka mengakibatkan plotter tersebut rusak atau patah. Karena syarat sebuah konstruksi atau komponen faktor keamanan harus lebih dari 1 agar aman saat digunakan.

\section{2) Desain awal plotter dengan bahan PETG}

Dengan dimensi dan massa yang sama, tetapi jenis bahan plastik yang digunakan berbeda dengan plotter sebelumnya (bahan PLA) maka hasil simulasi pada plotter tersebut adalah sebagai berikut:

\section{a) Strees (Tegangan)}

Hasil tegangan pada desain awal plotter

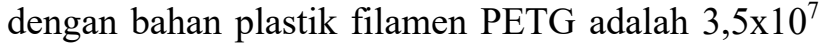
$\mathrm{N} / \mathrm{m}^{2}$ untuk tegangan maksimalnya (berwarna merah) dan untuk tegangan minimalnya adalah $2,9 \times 10^{6}$ $\mathrm{N} / \mathrm{m}^{2}$. 


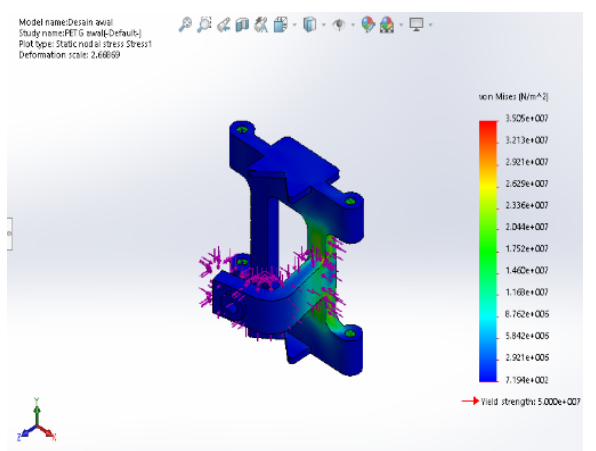

Gambar 15. Hasil Strees Desain Awal Plotter dengan Bahan PETG

\section{b) Displacement (Perubahan Bentuk)} Hasil Displacement pada plotter tersebut adalah $2,1 \mathrm{~mm}$.

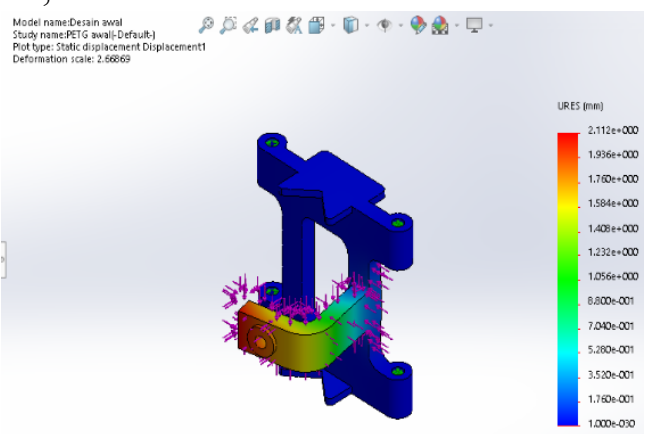

L

Gambar 16. Hasil Displacement desain awal plotter dengan bahan PETG

\section{c) Strain (Regangan)}

Hasil Strain (regangan) pada plotter tersebut adalah $1,0 \times 10^{-2} \mathrm{~N} / \mathrm{m}^{2}$.

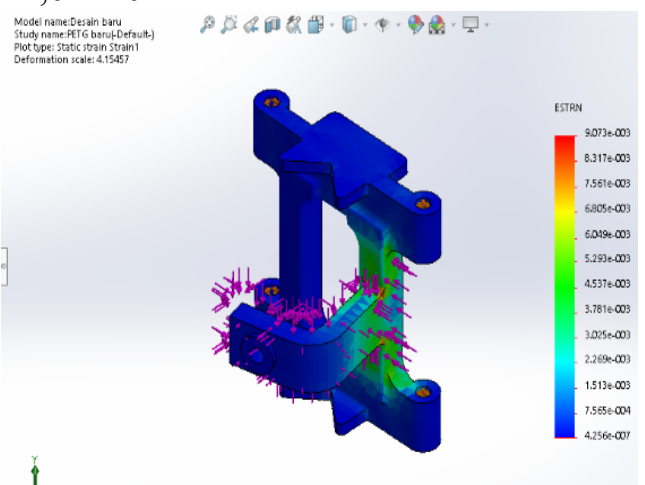

Gambar 17. Hasil Strain desain awal plotter dengan bahan PETG

d) Factor Of Safety/FOS (Faktor Keamanan)

Hasil Factor Of safety (faktor keamanan) pada plotter tersebut adalah 1,4.

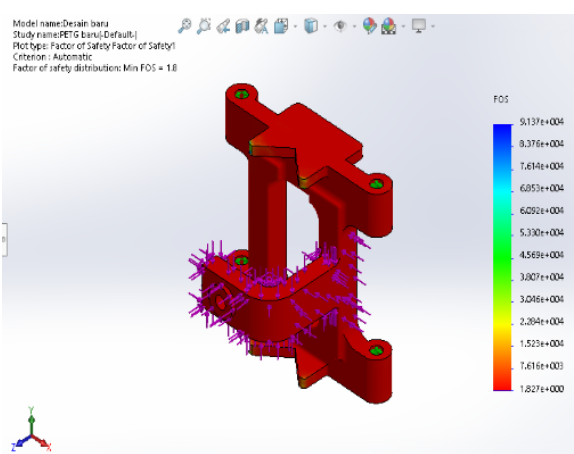

Gambar 18. Hasil Factor of safety desain awal plotter dengan bahan PETG

\section{3) Desain baru plotter dengan bahan PETG}

Dengan dimensi, massa dan jenis bahan plastik yang digunakan berbeda dengan plotter sebelumnya (bahan PLA) maka hasil simulasi pada plotter tersebut adalah sebagai berikut:

a) Strees (Tegangan)

Hasil tegangan pada desain baru plotter dengan bahan plastik filamen PETG adalah $2,7 \times 10^{7} \mathrm{~N} / \mathrm{m}^{2}$ untuk tegangan maksimalnya (berwarna merah) dan untuk tegangan minimalnya adalah $2,2 \times 10^{6} \mathrm{~N} / \mathrm{m}^{2}$.

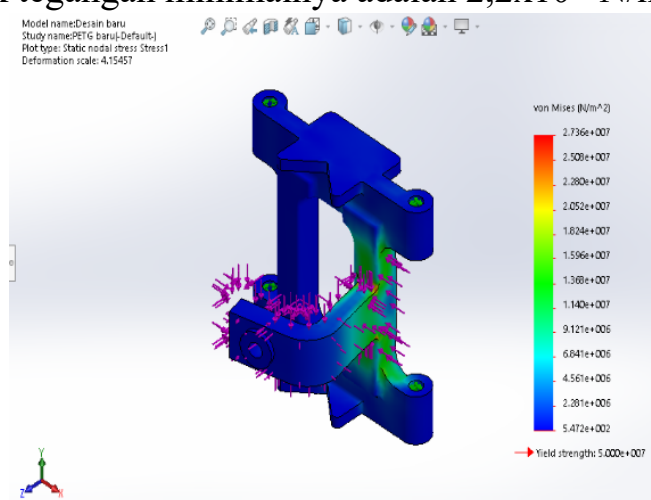

Gambar 19. Hasil Strees desain baru plotter dengan bahan PETG

b) Displacement (Perubahan Bentuk) Hasil Displacement pada plotter tersebut adalah $1,4 \mathrm{~mm}$.

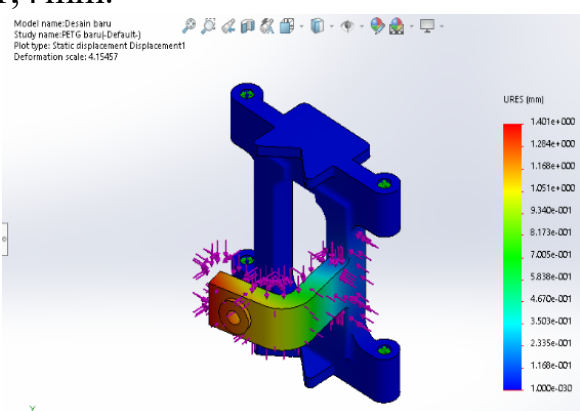

ג.

Gambar 20. Hasil Displacement Desain Baru Plotter dengan Bahan PETG 


\section{c) Strain (Regangan)}

Hasil Strain (regangan) pada plotter tersebut adalah $9,0 \times 10^{-3} \mathrm{~N} / \mathrm{m}^{2}$

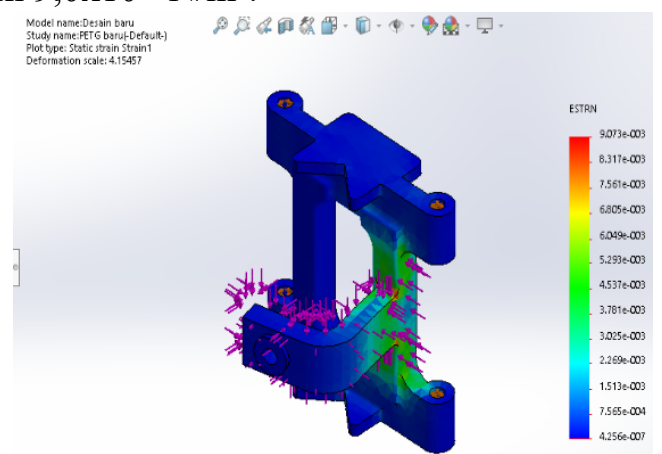

L.

Gambar 21. Hasil Strain desain baru plotter dengan bahan PETG

d) Factor Of Safety/FOS (Faktor Keamanan)

Hasil Factor Of Safety (faktor keamanan) pada desain baru plotter dengan bahan plastik filamen PETG adalah 1,8.

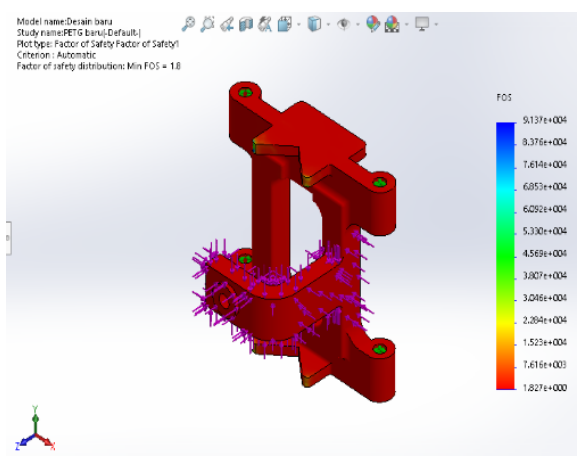

Gambar 22. Hasil Factor of safety desain baru plotter dengan bahan PETG

Desain dan bahan plotter yang berbeda akan menghasilkan reaksi yang berbeda terhadap pembebanan yang diberikan. Simulasi yang digunakan menggunakan Solidworks menghasilkan wujud Strees (tegangan) maksimal dan minimal, Strain (regangan) dan Displacement (perubahan bentuk) pada masing-masing plotter. Hasil analisis tersebut dapat digunakan untuk mengetahui apakah desain tersebut memenuhi kriteria yang ditetapkan, yaitu sama-sama berbahan plastik ringan dan aman untuk digunakan.

Setelah dilakukan analisis menggunakan solidworks, maka dapat diketahui bahwa tegangan maksimum pada desain awal dengan bahan plastik PLA adalah $4,0 \times 10^{7}\left(\mathrm{~N} / \mathrm{m}^{2}\right)$, tegangan pada desain awal dengan bahan plastik PETG adalah $3,5 \times 10^{7}$ $\left(\mathrm{N} / \mathrm{m}^{2}\right)$ sedangkan tegangan pada desain baru dengan bahan plastik PETG adalah $2,7 \times 10^{7}\left(\mathrm{~N} / \mathrm{m}^{2}\right)$, meskipun desain plotter baru dengan bahan PETG memiliki massa yang lebih berat dari desain

plotter yang sudah ada (awal), tetapi memiliki tegangan yang lebih rendah.

Disamping itu faktor yang perlu diperhatikan dalam desain konstruksi adalah faktor keamanan, sesuai dengan tujuan dari penelitian yaitu mengetahui perbandingan antara bahan PLA dan PETG. Keamanan suatu desain ditunjukkan dengan suatu nilai yang disebut faktor keamanan atau Factor $O f$ Safety. Penggunaan faktor keamanan paling banyak terjadi bila kita membandingkan tegangan dengan kekuatan untuk mendapatkan nilai angka keamanannya.

Untuk mengetahui material properties bahan plastik filamen PLA dan bahan plastik filamen PETG bisa dilihat pada tabel di bawah in

Tabel 2. Karakteristik Bahan PLA dan PETG

\begin{tabular}{|l|l|l|l|}
\hline No. & Karakteristik & $\begin{array}{l}\text { Bahan } \\
\text { PLA }\end{array}$ & $\begin{array}{l}\text { Bahan } \\
\text { PETG }\end{array}$ \\
\hline 1 & $\begin{array}{l}\text { Yield } \\
\text { Strength }\end{array}$ & $38 \mathrm{MPa}$ & $50 \mathrm{MPa}$ \\
\hline 2 & $\begin{array}{l}\text { Tensile } \\
\text { Strength }\end{array}$ & $50 \mathrm{MPa}$ & $53 \mathrm{Mpa}$ \\
\hline 3 & $\begin{array}{l}\text { Elastic } \\
\text { Modulus }\end{array}$ & $2000 \mathrm{MPa}$ & $2200 \mathrm{MPa}$ \\
\hline 5 & $\begin{array}{l}\text { Mass } \\
\text { Density }\end{array}$ & $\begin{array}{l}1300 \\
\mathrm{Kg} / \mathrm{m}^{3}\end{array}$ & $\begin{array}{l}1300 \\
\mathrm{Kg} / \mathrm{m}^{3}\end{array}$ \\
\hline 5 & $\begin{array}{l}\text { Shear } \\
\text { Modulus }\end{array}$ & $2400 \mathrm{Mpa}$ & $2600 \mathrm{MPa}$ \\
\hline
\end{tabular}

Dan untuk mengetahui perbandingan hasil simulasi plotter bisa dilihat pada tabel di bawah ini:

Tabel 3. Perbandingan Hasil Simulasi Plotter Bahan PLA dan PETG

\begin{tabular}{|l|l|l|l|l|}
\hline \multirow{2}{*}{ No } & Karakteristik & \multicolumn{2}{|l|}{ Desain Awal } & \multirow{2}{*}{$\begin{array}{l}\text { Desain } \\
\text { Baru }\end{array}$} \\
\cline { 3 - 4 } & & $\begin{array}{l}\text { Plotter } \\
\text { PLA }\end{array}$ & $\begin{array}{l}\text { Plotter } \\
\text { PETG }\end{array}$ & \\
\hline \multirow{2}{*}{1} & $\begin{array}{l}\text { Tegangan } \\
\text { Maks. }\end{array}$ & $\begin{array}{l}4,0 \times 10^{7} \\
\left(\mathrm{~N} / \mathrm{m}^{2}\right)\end{array}$ & $\begin{array}{l}3,5 \times 10^{7} \\
\left(\mathrm{~N} / \mathrm{m}^{2}\right)\end{array}$ & $\begin{array}{l}2,7 \times 10^{7} \\
\left(\mathrm{~N} / \mathrm{m}^{2}\right)\end{array}$ \\
\hline \multirow{2}{*}{2} & $\begin{array}{l}\text { Tegangan } \\
\text { Min. }\end{array}$ & $\begin{array}{l}3,3 \times 10^{6} \\
\left(\mathrm{~N} / \mathrm{m}^{2}\right)\end{array}$ & $\begin{array}{l}2,9 \times 10^{6} \\
\left(\mathrm{~N} / \mathrm{m}^{2}\right)\end{array}$ & $\begin{array}{l}2,2 \times 10^{6} \\
\left(\mathrm{~N} / \mathrm{m}^{2}\right)\end{array}$ \\
\hline 3 & Displacement & $2,7 \mathrm{~mm}$ & $2,1 \mathrm{~mm}$ & $1,4 \mathrm{~mm}$ \\
\hline 4 & Strain & $1,1 \times 10^{-}$ & $1,0 \times 10^{-}$ & $9,0 \times 10^{-}$ \\
2 & $2\left(\mathrm{~N} / \mathrm{m}^{2}\right)$ & $2\left(\mathrm{~N} / \mathrm{m}^{2}\right)$ & $3\left(\mathrm{~N} / \mathrm{m}^{2}\right)$ \\
\hline 5 & FOS & 0,9 & 1,4 & 1,8 \\
\hline
\end{tabular}

\subsection{Biaya bahan dan pengerjaan}

Untuk biaya bahan dan pengerjaan komponen plotter dengan desain baru di workshop 3D Printer yaitu sebesar Rp. 24.000 untuk bahan plastik filamen PLA dan Rp. 48.000 bahan plastik filamen PETG.

Karena dari segi dimensi dan massa plotter baru (bahan plastik PETG) berbeda dengan plotter 
yang sudah ada (bahan PLA), maka mempengaruhi biaya bahan dan pengerjaan di workshop 3D Printer.

Berikut ini adalah hasil percobaan pembuatan gambar/pola menggunakan plotter bahan PLA dan bahan PETG.

1) Hasil Percobaan ke 1

Dengan parameter "Conversion Tool Vectorize", "No Filling", "Speed 500 mm/min", ukuran input gambar $100 \times 17.5 \mathrm{~mm}$ dan polanya kata 'KREATIF'.

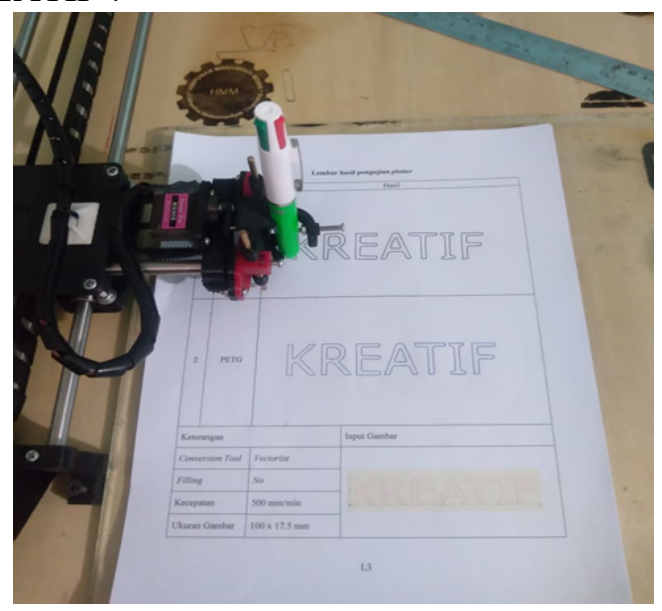

Gambar 22. Hasil Percobaan 1

2) Hasil Percobaan ke 2

Dengan parameter "Conversion Tool Vectorize", "Filling Horizontal", "Speed 500 $\mathrm{mm} / \mathrm{min}$ ", ukuran gambar $75 \times 23.4 \mathrm{~mm}$ dan polanya angka "2020".

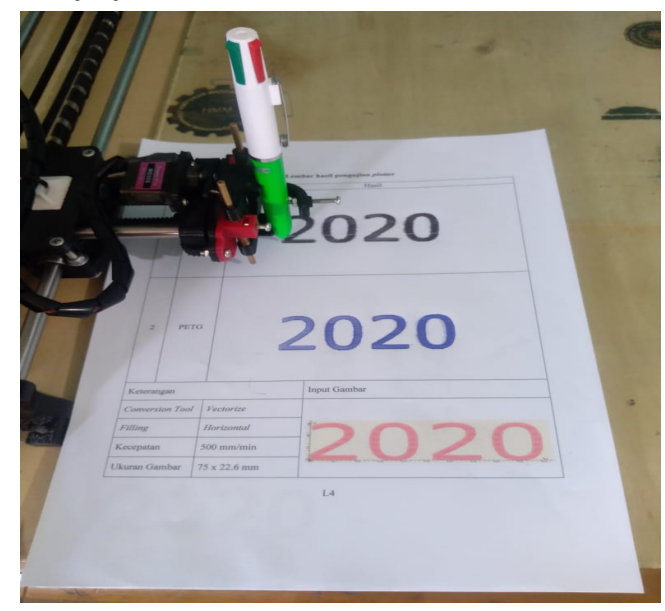

Gambar 23. Hasil Percobaan 3

3) Hasil Percobaan ke 3

Dengan parameter "Conversion Tool Vectorize", "Filling No", "Speed $480 \mathrm{~mm} / \mathrm{min} "$, ukuran gambar $88 \times 75.7 \mathrm{~mm}$ dan polanya gambarnya roda gigi dan tulisan.

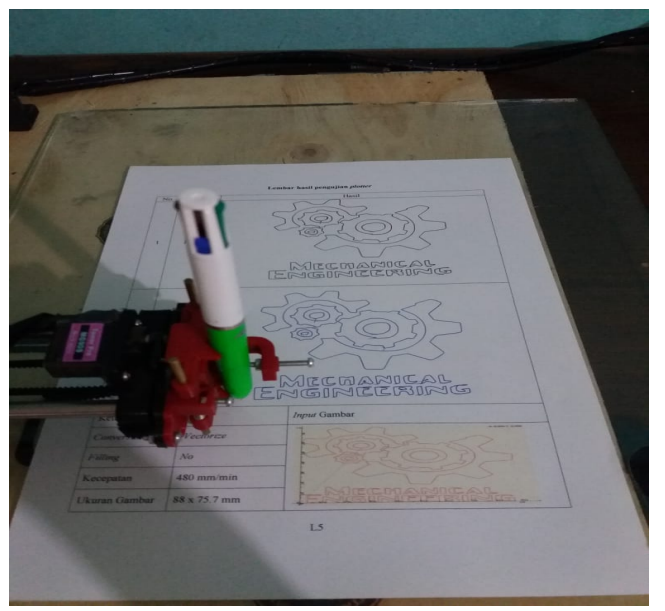

Gambar 24. Hasil Percobaan 4

Dari hasil percobaan ke 1, 2 dan 3 menggunakan plotter bahan PLA dan plotter bahan PETG penulis mengatur di setiap lembar percobaan masing-masing dengan pola, ukuran gambar dan kecepatan yang berbeda, maka mendapatkan hasil yang sama (tidak ada perbedaan).

\section{KESIMPULAN}

Kesimpulan dari penelitian di atas adalah sebagai berikut:

1) Pemilihan bahan disesuaikan dengan kebutuhan rancang bangun.

2) Komponen yang terjadi kerusakan adalah plotter (alat penjepit pulpen)

3) Perbandingan menggunakan plotter bahan plastik filamen PLA dan bahan plastik filamen PETG

dilihat dari simulasi dengan diberikan gaya sebesar 20 Newton maka:

Untuk desain awal plotter dengan bahan PLA, hasil tegangannya $4,0 \times 10^{7} \mathrm{~N} / \mathrm{m}^{2}$ melebihi angka yield strength yaitu $3,8 \times 10^{7} \mathrm{~N} / \mathrm{m}^{2}$ dan angka keamanannya 0,9 .

Untuk desain awal plotter dengan bahan PETG, hasil tegangannya $3,5 \times 10^{7} \mathrm{~N} / \mathrm{m}^{2}$ masih di bawah angka yield strength yaitu $5,0 \times 10^{7} \mathrm{~N} / \mathrm{m}^{2}$ dan angka keamanannya 1,4 .

Untuk desain baru plotter dengan bahan PETG, hasil tegangannya $2,7 \times 10^{7} \mathrm{~N} / \mathrm{m} 2$ masih di bawah angka yield strength yaitu $5,0 \times 10^{7} \mathrm{~N} / \mathrm{m}^{2}$. dan angka keamanannya 1,8 sehingga komponen plotter bahan PETG ini lebih kuat saat terjadi gaya sebesar 20 Newton.

Dilihat dari biaya bahan dan pengerjaan lebih mahal plotter desain baru dengan bahan plastik PETG daripada plotter desain awal dengan bahan plastik PLA, karena dari sisi dimensi plotter dan jenis plastik berbeda. 
Dilihat dari hasil percobaan 1, 2 dan 3 pembuatan gambar/pola hasilnya sama (tidak ada perbedaan) maka bahan plotter tidak berpengaruh terhadap hasil yang dikerjakan.

\section{DAFTAR PUSTAKA}

Azmi Yuliardi. 2020. Rancang Bangun Mesin CNC Mini Plotter Dua Sisi Tinta Dan Laser Diode Berbasis Microcontroller. Skripsi, Program Studi Teknik Mesin Fakultas Teknik, Universitas Pancasakti Tegal.

Diki Muhamad Sobirin, Jana Utama. Perancangan Sistem Multi Computer Numerical Control (CNC) Untuk Plotter Dan Laser Engraving. Jurnal Sistem Komputer, Universitas Komputer Indonesia, 2020.

Fifi Fauziah Yasmin. 2019. Analisa Kecepatan Motor Stepper Pada Mesin CNC Mini Plotter 2 Axis Laser Berbasis Microcontroller. Skripsi, Program Studi Teknik Mesin Fakultas Teknik, Universitas Pancasakti Tegal.

Hafiz Ramadhani, Syafri. Perancangan Dan Analisis Struktur Mekanik Prototipe Laser Cutting. Jom FTEKNIK Volume 5 No.1 April 2018.

Harist Fauzi. 2018. Rancang Bangun Sistem Kontrol Mesin Laser Engraving Dengan Microcontroller Arduino. Skripsi, Program Studi Teknik Mesin, Fakultas Teknik, Universitas Presiden Cikarang.

https://id.wikipedia.org/wiki/Mekatronika (diakses pada 28/7/20 pukul 20.00 WIB)

http://urbanlabs.co.in/products/petg-page (diakses pada $25 / 10 / 2020$ pukul 10.00 WIB)

Irpandi. 2018. Rancang Bangun Konstruksi Mesin Laser Engraving. Skripsi, Program Studi Teknik Mesin, Fakultas Teknik, Universitas Presiden Cikarang.

Much Aries Setiawan. 2013. Pengembangan Desain Frame Chassis Micro Car (Sutera Car) Universitas Negeri Semarang. Skripsi, Program Studi Pendidikan Teknik Mesin, Fakultas Teknik, Universitas Negeri Semarang.

Munadi, Aulia Syukri, Joga D. Setiawan, Mochammad Ariyanto. Rancang Bangun Prototipe Mesin CNC Laser Engraving Dua Sumbu Menggunakan Diode Laser. Jurnal Teknik Mesin Indonesia, 2018. Vol. 13, No. 1.

Sularso, Kiyokatsu Suga. 2017. Dasar Perencanaan Dan Pemilihan Elemen Mesin. Jakarta: Pradnya Paramita. 